\title{
Fertiliser Nitrogen and Factors Affecting Pasture Responses
}

\author{
Xuezhao Sun ${ }^{1}$, Nina Luo ${ }^{2}$, Bob Longhurst ${ }^{2}$ and Jiafa Luo ${ }^{*}, 2$ \\ ${ }^{1}$ AgResearch, Grasslands Research Centre, Palmerston North, New Zealand \\ ${ }^{2}$ AgResearch, Ruakura Research Centre, Hamilton, New Zealand
}

\begin{abstract}
Nitrogen (N) is an essential plant element. However, its supply from soil compared to its demand by crops as well as pasture plants is the most limiting amongst soil nutrients. Pastures respond well to $\mathrm{N}$ application. $\mathrm{N}$ utilization efficiency can be $9-28 \mathrm{~kg}$ dry matter per $1 \mathrm{~kg} \mathrm{~N}$ applied. As a result, $\mathrm{N}$ fertilisers are increasingly applied for high pasture production. How pastures respond to $\mathrm{N}$ and the factors affecting responses are crucial to the efficient use of $\mathrm{N}$ fertilisers. After fertiliser $\mathrm{N}$ is applied, $\mathrm{N}$ is rapidly absorbed into plants and growth stimulated via improvement of root systems and photosynthetic activity. Pasture production increases depend on botanical composition, cultivars and physiological state. Pasture growth is improved immediately after $\mathrm{N}$ application. This effect can last into the next growing period following initial defoliation. The carryover $\mathrm{N}$ effect may increase plant growth, but can be negative in some cases. New Zealand studies showed positive $\mathrm{N}$ carryover effects present for first two cuts, inconsistent at third, and negative for fourth and fifth cuts. Pasture composition, $\mathrm{N}$ fixation by legumes and herbage nutrient concentration all respond to $\mathrm{N}$ application. Pastures response to $\mathrm{N}$ flux varies with various factors, including $\mathrm{N}$ form, rate applied, and frequency and timing of application. Dry matter yields in pure grass pastures increases linearly with $\mathrm{N}$ application rate up to $200-400 \mathrm{~kg} \mathrm{~N}^{-1}$ per year. Split $\mathrm{N}$ applications improve annual yield and seasonal yield distribution. Spring applications gave greater $\mathrm{N}$ responses than autumn applications. $\mathrm{N}$ responses are also affected by climate, geographical factors, and soil factors, such as type, texture, drainage, $\mathrm{pH}$, fertility, moisture and temperature.
\end{abstract}

Keywords: Nitrogen, fertiliser, pasture, yield.

\section{INTRODUCTION}

Nitrogen $(\mathrm{N})$ is required by pastures at greater concentrations than any other essential nutrient. Pasture $\mathrm{N}$ requirements can be met from mineralisation of soil organic N, Nfixation by legumes, and externally from $\mathrm{N}$ fertiliser and animal excreta. The amount of biological $\mathrm{N}$ fixation depends on factors such as legume species, soil and climatic conditions, nutrient supply. Biological $\mathrm{N}$ fixation rates range between $100-300 \mathrm{~kg} \mathrm{ha}^{-1} \mathrm{yr}^{-1}$ for grass/clover pastures in New Zealand (NZ) [1]. Although $\mathrm{N}$ can be provided from these sources, insufficient soil $\mathrm{N}$ in NZ grass-dominant pastures is the primary limiting factor of production [2] and pasture responses to $\mathrm{N}$ fertiliser are still very sensitive.

The primary purpose for using $\mathrm{N}$ fertilisers is to increase pasture yield and, as a result of high $\mathrm{N}$ responses, $\mathrm{N}$ fertiliser usage has steadily increased. Early research focused on effects of $\mathrm{N}$ on dry matter (DM) production [3-6], herbage quality [7,8], pasture composition [9], and technology of $\mathrm{N}$ fertiliser application [4-6,10].

Fertilisation of pasture with phosphorus (P), sulphur (S) and other nutrients to stimulate symbiotic $\mathrm{N}$ fixation for $\mathrm{N}$ supply has been considered to be more cost-effective than direct application of $\mathrm{N}$ fertiliser [2]. $\mathrm{N}$ fertiliser application was suggested only after legume production was maximised under a high soil fertility status in terms of $\mathrm{P}$, potassium $(\mathrm{K})$, $\mathrm{S}$, lime and trace elements [11]. How to stimulate symbiotic

*Address correspondence to this author at the AgResearch, Ruakura Research Centre, Hamilton, New Zealand; Tel: 0064 78385125;

E-mail: Jiafa.Luo@agresearch.co.nz
$\mathrm{N}$ fixation was therefore intensively studied. These findings were published in a series of papers in the first issue of 1979 in NZ Journal of Experimental Agriculture. Effect of N application on $\mathrm{N}$ fixation was also studied [1].

With the increasing use of $\mathrm{N}$ fertiliser, interest has shifted to environmental issues arising from public concern over larger $\mathrm{N}$ applications [12-15]. As $\mathrm{N}$ research focus changed, the primary purpose of $\mathrm{N}$ fertiliser application for herbage production has since received less attention. This review focuses on the primary purpose for efficient use of $\mathrm{N}$ fertiliser. Thus, $\mathrm{N}$ responses and factors affecting $\mathrm{N}$ responses are summarised. $\mathrm{N}$ use efficiency has been defined in different ways [16]. In this review it is defined as a ratio of increased herbage DM production to fertiliser $\mathrm{N}$ applied.

\section{PLANT RESPONSE TO NITROGEN}

\section{Pasture Responses}

The first response of pastures to $\mathrm{N}$ fertiliser application is a rapid plant uptake of $\mathrm{N}$. Then grass tiller numbers and plant growth increases [17]. Fertiliser $\mathrm{N}$ applications increased tiller numbers of perennial ryegrass (PRG) (Lolium perenne) by $34 \%$ compared to nil $\mathrm{N}$ control [18].

Botanical species differ in their $\mathrm{N}$ response. As legumes can obtain $\mathrm{N}$ via fixation by Rhizobium bacteria they respond to $\mathrm{N}$ differently from grasses [17]. In Bulgaira, Lingorski et al. [19] found that there was little $\mathrm{N}$ response, from rate of $240 \mathrm{~kg} \mathrm{~N} \mathrm{ha}^{-1}$, of legumes, such as red clover (Trifolium pratense) and white clover (WC) (T. repens), while PRG increased DM yields by $134 \%$. Ledgard et al. [20] found that the production of WC grown with PRG in NZ sheep pastures 
decreased by 8,17 and $30 \%$ in Years 1, 2 and 3, respectively, at an application rate of $390 \mathrm{~kg} \mathrm{~N} \mathrm{ha}^{-1}$ per year. Decreased DM production was similar among cultivars. Harris and Clark [21] reported depressions in WC content in dairy pasture of 17,11 and $2 \%$ at the rates of 0,200 and $400 \mathrm{~kg} \mathrm{~N}$ $\mathrm{ha}^{-1}$ per year, respectively, at a low stocking rate (SR) (3.2 cows ha-1). At a high SR (4.5 cows ha $\left.{ }^{-1}\right)$, WC contents were affected with less intensity, and were 15,15 and $7 \%$, for the 0,200 , and $400 \mathrm{~kg} \mathrm{~N} \mathrm{ha}^{-1}$ rates respectively, possibily due to improved pasture utilisation.

Because legumes respond less to $\mathrm{N}$ than grasses, grass dominant pastures will give greater responses to $\mathrm{N}$ [22]. Some grass species may respond to $\mathrm{N}$ better than others. Zemenchik and Albrecht [23] in USA found that apparent $\mathrm{N}$ recovery was 0.3 to $0.5 \mathrm{~kg} \mathrm{~N} \mathrm{~kg}^{-1} \mathrm{~N}$ applied for Kentucky bluegrass (Poa pratensis L.), 0.2 to 0.4 for smooth brome grass (Bromus inermis Leyss.) and 0.3 to 0.5 for orchard grass. $\mathrm{N}$ utilisation efficiency was $12-18 \mathrm{~kg} \mathrm{DM} \mathrm{kg}^{-1} \mathrm{~N}$ for Kentucky bluegrass, 9-16 for smooth brome grass and 11-28 for orchard grass. Orchard grass is more sensitive to $\mathrm{N}$ than PRG, timothy (Phleum pratense), meadow fescue (Festuca pratensis) and Agrostis species in Britain [24]. Poa trivialis was found to give a greater response than PRG in winter/early spring in the Manawatu, NZ [17]. Italian ryegrass (Lolium multiforum) is more sensitive to $\mathrm{N}$ than PRG [17]. O'Conner [25] suggested that differences in response among grass species result largely from climatic conditions under which grasses have different growth rates.

With 9 cultivars of WC grown with PRG in NZ, Ledgard et al. [20] did not find a significant interaction in DM production between cultivars and $\mathrm{N}$, indicating that the different cultivars gave a similar response to N. However, an interaction in $\mathrm{N}$ fixation and cultivars was found [20]. With a high rate of $\mathrm{N}$ application (390 $\mathrm{kg} \mathrm{N} \mathrm{ha}^{-1}$ per year), $\mathrm{N}$ fixation declined in most WC cultivars, except for cultivars "Kopu" and "Ara".

Ryegrass ecotypes affect $\mathrm{N}$ response. Wedderburn et al. [26] collected PRG from 60 sites throughout the North Island hill country of NZ. PRGs removed from steep slopes with severe $\mathrm{N}$ deficiency were found to respond to $\mathrm{N}$ less than those removed from a less stressed environment. PRG which is tolerant to $\mathrm{N}$ deficiency does not respond well after relief of $\mathrm{N}$ deficiency with $\mathrm{N}$ added. Bahmani et al. [27] studied two PRG ecotypes, "Ellett", representing the Mangere ecotype from which many modern cultivars were bred, and "Grasslands Ruanui", representing an older Hawke's Bay ecotype. Although significant differences between the two ecotypes in herbage accumulation and tiller weight were not found, greater tillering responses to $\mathrm{N}$ were found with "Grasslands Ruanui" compared with "Ellett" (+8698 vs +969 tillers $\mathrm{m}^{-2}$ ).

Once reproductive tillers are elongating, nutrients in plant are mainly provided to the reproductive tillers, leading to little activity in vegetative parts while some vegetative tillers die, no matter whether $\mathrm{N}$ fertiliser is applied [17]. The growth of the reproductive tiller is limited to enlarge organs already formed, rather than to form new plant parts. Thus reproductive tillers limit the expression of grass response to $\mathrm{N}$. Therefore, the ratio of vegetative to reproductive tillers affects $\mathrm{N}$ response.
Carryover effect has been frequently reported [25,28-30]. Trials conducted in Southland and Central Otago, NZ, indicated that pasture responses to May application at a rate of $50 \mathrm{~kg} \mathrm{~N} \mathrm{ha}^{-1}$ lasted to October [29]. Trials conducted in the Waikato, NZ, with a single application of urea at rates of 0 , $25,50,100 \mathrm{~kg} \mathrm{~N} \mathrm{ha}^{-1}$ over different times of the year also indicated a carryover effect [28]. When growing conditions are not favourable after $\mathrm{N}$ application or the cutting is shortly after $\mathrm{N}$ application, positive carryover effects will appear [25].

Carryover effect of $\mathrm{N}$ application does not always increase pasture growth, but sometimes reduces yield. Feyter et al. [28] found that, in general, cuts 1 and 2 gave a positive response but cuts 4 and 5 slightly negative, with cut 3 responses inconsistent. In these trials the negative response was suggested to have resulted from the depression of $\mathrm{WC}$ rather than nutrient deficiency. O'Connor [25] also suggested that negative DM responses resulted from reduced proportion of clover following $\mathrm{N}$ application. Ball and Field [17] suggested the reduction in pasture growth is due to deficiency of other nutrients in low-producing swards. However, many crops fail to show $\mathrm{N}$ responses, especially when other factors are limiting growth. For example, Strong et al. [31] applied $\mathrm{N}^{15}$-depleted ammonium nitrate to wheat crop. They found the recovery of residual fertiliser $\mathrm{N}$ after the first wheat crop was harvested was very low, usually less than $10 \%$. To directly illustrate the $\mathrm{N}$ carryover effect in pasture, studies with $\mathrm{N}^{15}$-depleted fertiliser are needed.

\section{Pasture Composition}

Since legumes and grasses have differential responses to $\mathrm{N}$, pasture composition affects response. On the other hand, $\mathrm{N}$ application also changes pasture composition. From 158 trials conducted in $\mathrm{PRG} /$ clover pastures in NZ with an application of $100 \mathrm{~kg} \mathrm{~N} \mathrm{ha}^{-1}$ in spring and autumn, O'Connor [25] concluded that grasses increase in the proportion of pasture composition, whereas clovers decrease. The same conclusion was drawn by Feyter et al. [28]. The clover decrease is due to a suppression suffered from shading of grasses since grasses are more responsive than clovers to $\mathrm{N}$ fertiliser. Although the proportion of clover decreases, clover yield does not necessarily reduce. However, in some cases, the clover proportion does not decline. For example, in WC-dominant pastures of Southland and Central Otago in NZ, WC proportion did not reduce with $\mathrm{N}$ application [29]. This may be due to extra cuts stopping grasses giving shading to WC. The depression of WC proportion by $\mathrm{N}$ application may be overcome with appropriate mowing or grazing management.

Changes of botanical composition in pasture vary with region and season. Clover content can be kept to $20 \%$ or more in northern North Island, NZ, while it is reduced to $<5 \%$ in South Island, NZ [25]. The loss of WC in WC/PRG pasture mainly occurs in late winter [32]. The competitive ability of clovers is weaker in cooler conditions than in warm conditions probably because the major limiting factor for WC growth is temperature while $\mathrm{N}$ supply limits grass growth [32]. The proportion of $\mathrm{WC}$ in the sown pasture of orchard grass, PRG and WC decreased with increase in $\mathrm{N}$ application at rates of $0,150,300 \mathrm{~kg} \mathrm{~N}^{-1}$ in the Cheju brown volcanic ash soil in Korea [33]. A long-term (35 years) experiment in Poland also showed that $\mathrm{N}$ application 
reduced species diversity in the sward and increased the proportion of acid soil species (e.g. Nardus stricta and Vaccinium myrtillus) [34].

\section{Nitrogen Fixation}

$\mathrm{N}$ application reduced $\mathrm{N}_{2}$ fixation by legumes. Ledgard et al. [1] found that $1 \mathrm{~kg} \mathrm{~N}$ applied reduced $0.27 \mathrm{~kg} \mathrm{~N}$ fixed by WC. The contribution of $\mathrm{N}_{2}$ fixation to clover $\mathrm{N}$ dropped from $77 \%$ in the $0 \mathrm{~N}$ treatment to $43 \%$ in the $400 \mathrm{~kg} \mathrm{~N}$ treatment at a high stocking rate (SR), showing substitution of fertiliser $\mathrm{N}$ for $\mathrm{N}_{2}$ fixation [1]. This study also suggested that the reduction resulted mainly from the depression of WC production. This is supported by the evidence that clover growth and $\mathrm{N}_{2}$ fixation were decreased by past $\mathrm{N}$ use, but not by recent $\mathrm{N}$ application [35]. However, in general, with increasing mineral $\mathrm{N}$ concentration in soil, the activity of the $\mathrm{N}$ symbiosis declines [36]. Calculation of data presented in Ledgard et al. [1] indicates that clover production decreased by 21,60 and $43 \%$ at rates of $200 \mathrm{~kg} \mathrm{~N} \mathrm{ha}^{-1}, 400 \mathrm{~kg} \mathrm{~N} \mathrm{ha}^{-1}$ with a low SR, $400 \mathrm{~kg} \mathrm{~N}^{-1}{ }^{-1}$ with a high SR, respectively. These results show a large reduction in the total annual amount of $\mathrm{N}_{2}$ fixation, 36,75 and $65 \%$ for the respective treatments. In a study by Cookson et al. [37], the amount of $\mathrm{N}$ fixed from the atmosphere significantly decreased after the first $30 \mathrm{~d}$ of re-growth, suggesting that $\mathrm{N}_{2}$ fixation activity decreased. After a high rate of $\mathrm{N}$ application, clover plant morphology changed. In the $400 \mathrm{~kg} \mathrm{~N} \mathrm{ha}^{-1}$ treatment, the length and number of stolons reduced, the nodule number and mass per plant or per unit of root weight decreased [21]. Inappropriate application of $\mathrm{N}$ can sometimes be toxic directly or by reducing root growth. These changes may also be related to the reduction of $\mathrm{N}_{2}$ fixation activity. Therefore, decreases both in symbiotic activity and in clover growth contributed to reduction of $\mathrm{N}_{2}$ fixation.

\section{Nutrient Concentration in Herbage}

The initial $\mathrm{N}$ uptake by grasses within two to three weeks after $\mathrm{N}$ application is rapid and luxurious, faster than the rate used by plants to produce growth, resulting in accumulation of nitrogenous compounds, including nitrate-N, in herbage. High nitrogenous compound accumulation after $\mathrm{N}$ application was found in various forages, e.g., in kikuyu grass (Pennisetum clandestinum) [38], in PRG [39,40] and Italian ryegrass [39], in the mixed sward of smooth brome grass, Elymus nutans, E. sibricus, Agropyron cristatum [41], in a mixed sown grassland of orchard grass, PRG and WC [33]. $\mathrm{N}$ concentration in herbage decreases with time [17]. If pasture was harvested 19-38 days or longer after $\mathrm{N}$ application, the increase in $\mathrm{N}$ content was small [28].

In general, $\mathrm{N}$ fertiliser has little effect on the concentration of mineral elements in herbage and is of little importance in practice $[2,28,42]$. But, Pederson et al. (2002) noted that in the aboveground part of Italian ryegrass $\mathrm{N}$ concentration was highly correlated with $\mathrm{P}, \mathrm{Cu}$ and $\mathrm{Zn}$ concentrations. After reviewing a large number of studies, Ball and Field [17] found that the effects of $\mathrm{N}$ fertilisers on mineral composition of pastures were inconsistent.

Variation in the result of mineral elements may come from the form of $\mathrm{N}$ fertiliser used, changes of botanical composition and soil type. $\mathrm{N}$ fertilisers contain other mineral elements which can be taken up by plants and subsequently alter chemical composition in herbage. Clovers contain more $\mathrm{N}$, calcium $(\mathrm{Ca})$, magnesium $(\mathrm{Mg})$ and certain trace elements than grasses [17]. Changes in botanical composition would change mineral composition in the pasture.

Water-soluble carbohydrate concentration reduced with increasing rate of $\mathrm{N}$ fertiliser application in the range of 0 $630 \mathrm{~kg} \mathrm{~N} \mathrm{ha}^{-1}$ per year in Ireland [39], but a decrease was not found in an Australian study [40] at application rates of 25, 50 and $75 \mathrm{~kg} \mathrm{~N} \mathrm{ha}^{-1}$. DM digestibility was inconsistent to $\mathrm{N}$ application. DM digestibility was not affected with $\mathrm{N}$ application in PRG, but reduced in Italian ryegrass [39]. Researchers in Brazil also did not find digestibility improved after $\mathrm{N}$ application in aruana grass (Panicum maximum Jacq) pasture and aruana grass pasture oversown with black oat (Avena strigosa Schreb) and Italian ryegrass [43]. Metabolisable energy and neutral detergent fibre were not affected in PRG [40].

\section{FACTORS OF FERTILISER APPLICATION AFFECT- ING NITROGEN RESPONSE}

\section{Nitrogen Form}

Nitrogen exists in chemical fertilisers in the nitrate $\left(\mathrm{NO}_{3}\right.$ $\mathrm{N})$, ammonium $\left(\mathrm{NH}_{4}-\mathrm{N}\right)$ or urea form. Urea fertilizer undergoes the ammonification reaction in soil (Eq. 1), known as 'urea hydrolysis', and is carried out in the presence of the urease enzyme. In this process $\mathrm{NH}_{4}{ }^{+}$ions are produced which also releases hydroxyl $\left(\mathrm{OH}^{-}\right)$ions and hence the $\mathrm{pH}$ around the urea granules in soil increases to a maximum of 8.

\section{(Eq. 1) $\mathrm{CO}\left(\mathrm{NH}_{2}\right)_{2} \rightarrow 2 \mathrm{NH}_{4}^{+}+2 \mathrm{OH}^{-}+\mathrm{CO}_{2}$}

The nitrification process produces $\mathrm{H}^{+}$ions, thereby decreasing the $\mathrm{pH}$ (Eq. 2). Since, per unit $\mathrm{N}$, more $\mathrm{H}^{+}$ions are produced during nitrification than $\mathrm{OH}^{-}$ions during ammonification, urea fertiliser ultimately acidify the soils (Eq. 3). Ammonium fertilisers undergo only the nitrification process releasing $\mathrm{H}^{+}$ions. This is one of the reasons why these fertilisers are more acidifying than urea fertiliser.

(Eq. 2) $2 \mathrm{NH}_{4}^{+}+4 \mathrm{O}_{2} \rightarrow 2 \mathrm{NO}_{3}{ }^{-}+4 \mathrm{H}^{+}+2 \mathrm{H}_{2} \mathrm{O}$

(Eq. 3) Net effect $\mathrm{CO}\left(\mathrm{NH}_{2}\right)_{2} \rightarrow 2 \mathrm{NO}_{3}{ }^{-}+2 \mathrm{H}$

Mineral $\mathrm{N}$, in either $\mathrm{NO}_{3}-\mathrm{N}$ or $\mathrm{NH}_{4}-\mathrm{N}$ forms, can be taken up by plants. Urea can not be directly absorbed unless it is sprayed on the leaf surface. Urea in soil must be hydrolysed to $\mathrm{NH}_{4}{ }^{+}$before it is absorbable with plants and $\mathrm{NH}_{4}{ }^{+}$ may further nitrified. Ammonium-N is rapidly converted to nitrate- $\mathrm{N}$ in soil by microbes when soil moisture and temperature are suitable to microbial activities. $\mathrm{NH}_{4}-\mathrm{N}$ is predominant in soil during cool, wet conditions [44]. In NZ, pasture species take up most of the $\mathrm{N}$ in the form of nitrate. Nitrate-N after being absorbed into plants will be converted to ammonium- $\mathrm{N}$ for incorporation into protein metabolism. In theory ammonium- $\mathrm{N}$ is more efficient for plants. This is supported by the evidence of Italian ryegrass having preference for ammonium- $\mathrm{N}$ from an experiment under hydroponic conditions [45]. In a field experiment in Oregon, USA, different $\mathrm{N}$ sources gave similar DM yields of Italian ryegrass to $200 \mathrm{~kg} \mathrm{~N} \mathrm{ha}^{-1}$ as calcium nitrate $(\mathrm{CN})$, ammonium nitrate (AN), ammonium sulphate (AS), ammonium chloride (AC), or urea-dicyandiamide (DCD) [44]. However, better seed production has been obtained using ammonium nitrate. 
Table 1. Total Pasture Consumed and N Efficiency after Application of Differing Amounts of Nitrogen after Each Or Every Second Grazing

\begin{tabular}{|c|c|c|c|c|c|}
\hline \multirow{2}{*}{$\begin{array}{c}\text { N Treatment } \\
\text { (kg N per Grazing) }\end{array}$} & \multirow{2}{*}{ 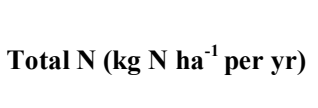 } & \multicolumn{2}{|c|}{ Total Pasture Consumed (t DM ha ${ }^{-1}$ ) } & \multicolumn{2}{|c|}{ N Efficiency (Increased $\mathrm{kg} \mathrm{DM} \mathrm{kg}^{-1} \mathrm{~N}$ Applied) } \\
\hline & & Year 1 & Year 2 & Year 1 & Year 2 \\
\hline 0 & 0 & 9.1 & 6.3 & & \\
\hline 25 & 175 & 10.8 & 8.2 & 9.5 & 15.4 \\
\hline 50 & 350 & 11.5 & 8.8 & 6.8 & 10.3 \\
\hline 75 & 525 & 12.8 & 9.8 & 7 & 9.5 \\
\hline 100 & 700 & 12.1 & 9.4 & 4.3 & 6.3 \\
\hline $50 / 2$ nd & 150 & 11.4 & 8.6 & 15.5 & 15.5 \\
\hline $100 / 2$ nd & 300 & 11.0 & 9.8 & 6.3 & 11.7 \\
\hline $150 / 2 \mathrm{nd}$ & 450 & 12.2 & 10.2 & 6.8 & 8.7 \\
\hline $200 / 2$ nd & 600 & 11.9 & 9.5 & 4.7 & 5.4 \\
\hline
\end{tabular}

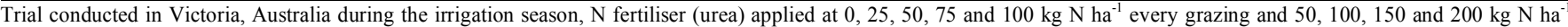
every second grazing

Adapted from McKenzie et al. [46]

In NZ, pasture responses to different forms of $\mathrm{N}$ are similar over the whole season [17]. Only in conditions of low soil temperature, and irrigation or high rainfall, do $\mathrm{N}$ forms perform differently.

\section{Rate of Nitrogen Application}

DM production commonly increases with an increasing rate of $\mathrm{N}$ application, but $\mathrm{N}$ efficiency decreases $[25,28,46]$. Table 1 shows a decrease of $\mathrm{N}$ efficiency with an increasing rate of $\mathrm{N}$ application. Pure grass pasture generally has a linear response to application rates up to $200-400 \mathrm{~kg} \mathrm{~N} \mathrm{ha}^{-1}$ per year [47].

\section{Frequency of Nitrogen Application}

Splitting $\mathrm{N}$ applications may not consistently increase herbage DM yields [28,48-50]. However, other studies found that increasing the frequency of $\mathrm{N}$ application at the same rate normally increased forage production [51-52]. Malhi et al. [52] applied AN at split rates of 60,120 and $180 \mathrm{~kg} \mathrm{~N}^{-1}$ to smooth brome grass on a Black Chernozemic (Udic Boroll) soil in Central Alberta, Canada. The treatments included single (100\% in autumn or spring), split 50 (applied $50 \%$ in autumn or spring, $25 \%$ after cut 1 and $25 \%$ after cut 2 ) and split $33(33 \%$ applied in autumn or spring, 33\% after cut 1 and $33 \%$ after cut 2) modes of application. DM results indicated that split applications gave a greater annual yield increases than a single application and improved the seasonal distribution of herbage production.

\section{Time of Nitrogen Application}

Pasture response to $\mathrm{N}$ varies with seasons (Fig. 1). For example, average pasture responses across 25,50 and $100 \mathrm{~kg}$ $\mathrm{N}^{-1}$ were $6.7,8.6,3.8,12.0,12.3,11.6$ and $8.5 \mathrm{~kg} \mathrm{DM} \mathrm{kg}^{-1}$ $\mathrm{N}$ with $\mathrm{N}$ application in March, April, May, June, July, August and September, respectively, in East Coast pastures in NZ [53]. From over 400 trials conducted throughout New Zealand in 1970s, responses were always stronger in spring than in autumn. Pasture responses were also at least twice higher and more reliable in spring than in autumn [25]. The poorer response in autumn was suggested to result from lim- ited soil moisture, high soil mineral $\mathrm{N}$ level and high proportion of clovers [25]. $\mathrm{N}$ applications to pastures in winterearly spring were also better than in autumn on several soils in the Waikato region of NZ [28].

Application of $\mathrm{N}$ fertiliser after defoliation may reduce pasture responses. In Hungry, Banszki [54] applied N fertiliser for the 2nd-4th growth of pasture on a leached, loamy soil at a rate of $75 \mathrm{~kg} \mathrm{ha}^{-1}$ on $0,5,10,15$ and 20 days after the previous cut. DM production for the 2nd-4th growth periods was reduced by $2-8 \%$ if $\mathrm{N}$ was applied 5-20 days later, with the greatest reduction 15 days after cut. The pasture height decreased by 2-6\% as well, but $\mathrm{N}$ content in herbage increased by $5-14 \%$.

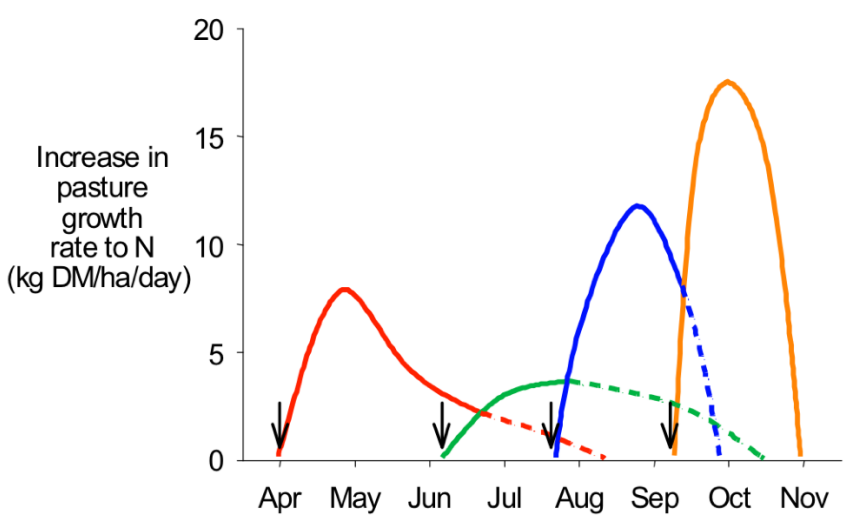

Fig. (1). Pasture responses to $\mathrm{N}$ application in different seasons in New Zealand. Arrows represent $\mathrm{N}$ applications (modified from Feyter et al. [28]).

\section{SOIL, CLIMATE AND GEOGRAPHICAL FACTORS AFFECTING NITROGEN RESPONSE}

\section{Soil}

Soil type influences availability of nutrients to plants. Therefore, other elements contained in $\mathrm{N}$ fertiliser can affect pasture response. In NZ, the Wharekohe silt loam is prone to nutrient leaching including $\mathrm{S}$ and $\mathrm{N}$. Sulphate of ammonia 
gave a higher DM response than urea and ASN (Table 2). In contrast, $\mathrm{S}$ was not a limiting element on marine clay where similar responses were found to the application of SA and urea.

Table 2. Pasture Responses (kg DM ha ${ }^{-1}$ ) to $\mathbf{N}$ Fertilisers on Wharekohe and Marine Clay Soils (Relative Yields to Control in Brackets). $N$ Applied in Mid Winter at Rate of $30 \mathrm{~kg} \mathrm{~N} \mathrm{ha}^{-1}$. $\mathrm{n}=3$

\begin{tabular}{|c|c|c|}
\hline Nitrogen Treatment & Wharekohe & Marine Clay \\
\hline \hline Control & $1230(100)$ & $1124(100)$ \\
\hline Urea & $1720(140)$ & $1456(130)$ \\
\hline Sulphate of ammonia & $2318(188)$ & $1450(129)$ \\
\hline Ammonium sulphate nitrate & $1925(157)$ & $1309(116)$ \\
\hline LSD 5\% & 315 & 265 \\
\hline
\end{tabular}

Feyter et al. [28] conducted an experiment with three soil types: Horotiu sandy loam (Allophanic), Te Kowhai fine sandy loam (Gley) and Te Rapa peaty loam (Organic). These authors found that although DM responses to $\mathrm{N}$ were similar on these three soil types, $\mathrm{N}$ application in April or May (autumn) gave a greater response (by about $65 \%$ ) on $\mathrm{Te}$ Rapa peaty loam than the other two soil types. The reason may be related to $\mathrm{N}$ mineralization rate. The large $\mathrm{C} / \mathrm{N}$ ratio in the peat soil reduces $\mathrm{N}$ mineralization, resulting in greater response to applied $\mathrm{N}$. When a soil has a very high $\mathrm{C} / \mathrm{N}$ ratio, $\mathrm{N}$ has to be used for the correction of the ratio.

Adjusting soil $\mathrm{pH}$ to an optimal 5.8-6.0 on mineral soils with lime is widely used in NZ on permanent pastures. Liming ameliorates aluminium ( $\mathrm{Al})$ and manganese $(\mathrm{Mn})$ toxicity, increases plant availability of N, P and molybdenum (Mo), and increases soil moisture [56]. In NZ, on a Mangatea soil (Podzol), N, P, and Mo availability increased and Al toxicity was ameliorated with increasing $\mathrm{pH}$ value. While on the Matapiro soil (Pallic), $\mathrm{N}$ mineralization was enhanced with $\mathrm{pH}$ increase.

In an experiment conducted on steep $\left(>30^{\circ}\right)$ north-facing hill pasture where Agrostis tenuis (A. capillaris), Festuca rubra and Anthoxanthum odoratum dominated and with some PRG and WC, Zhou et al. [57] found that after soil $\mathrm{pH}$ correction (increase of 0.24-0.30 pH units) with $2 \mathrm{t} \mathrm{ha}^{-1}$ lime, $\mathrm{N}$ use efficiencies increased in all seasons, especially in summer (Table 3) and PRG content increased, A. tenuis, $F$. rubra and $A$. odoratum contents decreased. The increase of $\mathrm{N}$ use efficiency with lime may be due to increased available mineral $\mathrm{N}$ and potential mineralisable $\mathrm{N}$, and increased soil moisture resulting from soil structural improvement.

Table 3. Nitrogen Response Efficiencies after Soil $\mathbf{p H}$ Adjustment with Lime Over Months

\begin{tabular}{|c|c|c|c|c|c|}
\hline Treatment & pH Increase & Sept & Nov & Dec & Jan \\
\hline \hline $80 \mathrm{~kg} \mathrm{~N} \mathrm{ha}^{-1}$ & & 3.5 & 5.0 & 9.9 & 29.3 \\
\hline $\begin{array}{c}80 \mathrm{~kg} \mathrm{~N} \mathrm{ha}^{-1} \\
+2 \mathrm{tha}^{-1} \text { lime }\end{array}$ & $0.24-0.3$ & 6.1 & 6.0 & 20.1 & 41.4 \\
\hline
\end{tabular}

Adapted from Zhou et al. [57]. Urea was applied.
Soil fertility varies largely in NZ. Soils on many sheep and beef farms have low fertility, while soils on dairy farms are normally kept at a high fertility level. Korte [53] noted that autumn response to $\mathrm{N}$ was larger at sites with low soil $\mathrm{N}$ than sites with higher soil N levels. In NZ developed pasture, responses to $\mathrm{N}$ are normally $10-15 \mathrm{~kg} \mathrm{DM} \mathrm{kg}^{-1} \mathrm{~N}$, but in low soil fertility North Island hill pasture, responses up to $41 \mathrm{~kg}$ $\mathrm{DM} \mathrm{kg}{ }^{-1} \mathrm{~N}$ were recoded [57]. Morton and Roberts conducted a fertiliser experiment in Westland, NZ on an extremely infertile "humped and hollowed" Pakihi soil and on a "flipped" soil under high rainfall $(2000-3000 \mathrm{~mm})$ and found that $\mathrm{N}$ efficiency decreased with year, suggesting $\mathrm{N}$ response decreases with the build-up of soil fertility [58].

When low soil fertility results from a deficiency of other nutrients rather than $\mathrm{N}$, responses to $\mathrm{N}$ will be improved once these nutrients are at sufficient concentrations. NZ hill country soil normally lacks $\mathrm{P}$. If adequate $\mathrm{P}$ is provided to achieve plant growth potential, optimised $\mathrm{N}$ responses can be expected [59]. However, Gillingham et al. [60] found that $\mathrm{N}$ increased grass DM production and decreased clover DM production at both low and high P fertility levels. Total annual production increased $719 \mathrm{~kg} \mathrm{ha}^{-1}$ from winter added $\mathrm{N}$ fertiliser $\left(30 \mathrm{~kg} \mathrm{~N} \mathrm{ha}^{-1}\right)$ in low $\mathrm{P}$ fertiliser, while it did not increase at high $\mathrm{P}$ fertiliser. The interaction between $\mathrm{N}$ and $\mathrm{P}$ appeared only in winter and autumn (Table 4).

Table 4. DM Responses $\left(\mathrm{kg} \mathrm{ha}^{-1}\right)$ of Grass, Clover and Total Annual Production to N Under High and Low P Fertilization

\begin{tabular}{|c|c|c|c|}
\hline Treatment & Grass & Clover & Total \\
\hline Low $\mathrm{P}$ & 2006 & 316 & 2322 \\
\hline Low $\mathrm{P}+\mathrm{N}$ & 2839 & 201 & 2040 \\
\hline High P & 2474 & 1111 & 3585 \\
\hline High $\mathrm{P}+\mathrm{N}$ & 2943 & 585 & 3528 \\
\hline \multicolumn{4}{|l|}{ significance } \\
\hline $\mathrm{N}$ & $* * *$ & $* *$ & NS \\
\hline $\mathrm{N} * \mathrm{P}$ & NS & $*$ & $*$ \\
\hline
\end{tabular}

From Gillingham et al. [60]. Low $\mathrm{P}=$ soil Olsen $\mathrm{P} 9 \mu \mathrm{g} \mathrm{ml}^{-1}$; High $\mathrm{P}=$ soil Olsen $\mathrm{P} 28$ $\mu \mathrm{g} \mathrm{ml}^{-1}$.

\section{Environmental Factors}

$\mathrm{N}$ response is limited by soil moisture. Only if soil moisture is adequate can reliable $\mathrm{N}$ responses be expected [59]. From trials in a high rainfall area of the Westland, NZ, Williams and Paterson [61] found that best responses were in September/October (up to $22 \mathrm{~kg} \mathrm{DM} \mathrm{kg}^{-1} \mathrm{~N}$ ) and March/April (up to $10 \mathrm{~kg} \mathrm{DM} \mathrm{kg}^{-1} \mathrm{~N}$ ). Pasture yield depressions were observed in weeks 13-15 after $\mathrm{N}$ was applied and were greatest in October and at higher rates.

Ammonium-N in soil can be "fixed" by soil colloids as it is positively charged, resulting in its immobilisation. Nitrate$\mathrm{N}$ is prone to leaching as it is negatively charged. Therefore, when irrigation water is applied, or in an area or a season with frequent high rainfall, ammonium-N provides better pasture responses than nitrate-N [62]. 
Temperate pastures do not grow at soil temperatures below $4^{\circ} \mathrm{C}$. At this temperature, no $\mathrm{N}$ response would be expected. At soil temperature between $4-10^{\circ} \mathrm{C}$, mineralisation of organic $\mathrm{N}$ is not sufficient to provide $\mathrm{N}$ for plant growth. Therefore, $\mathrm{N}$ from fertiliser is important for plant growth. When soil temperature is low, nitrate- $\mathrm{N}$ could be more effective than ammonium-N and urea-N. At low soil temperatures $\left(6-8^{\circ} \mathrm{C}\right)$, plants take up more nitrate-N than ammonium-N. This may result from more mobile nitrate-N. Soil microbes are involved in the hydrolysis and nitrification of urea-N. It would be expected that low temperature limits plant responses to urea [63].

Craighead et al. [63] measured ryegrass/WC pasture responses in South Canterbury, NZ to four forms of fertilisers (calcium ammonium nitrate (CAN), ASN, AS, and urea) at $30 \mathrm{~kg} \mathrm{~N} \mathrm{ha}{ }^{-1}$ at three different soil temperatures. At $0-2^{\circ} \mathrm{C}$, $\mathrm{DM}$ yield differences among forms of fertiliser $\mathrm{N}$ were not significant (Table 5). Soil biological activity at $0-2^{\circ} \mathrm{C}$ is too low to nitrify urea and $\mathrm{NH}_{4}-\mathrm{N}$ to the $\mathrm{NO}_{3}$ form. Slow plant growth prevents them from fully benefiting from the nitrate$\mathrm{N}$. At $3-5^{\circ} \mathrm{C}, \mathrm{DM}$ production with $\mathrm{CAN}$ was significantly higher compared to other fertilisers. Nitrate- $\mathrm{N}$ is present in ASN also, but accounts for only $26 \%$ of total N. At $3-5^{\circ} \mathrm{C}$ soil temperature, air temperature was high enough for plants for active growth while soil microbes were still not active to convert urea-N or $\mathrm{NH}_{4}-\mathrm{N}$ to $\mathrm{NO}_{3}-\mathrm{N}$. Thus the advantage of nitrate- $\mathrm{N}$ was expressed. At $7-9^{\circ} \mathrm{C}$, there were no significant differences between the four $\mathrm{N}$ fertilisers. This may be because mineralisation of organic $\mathrm{N}$ to inorganic $\mathrm{N}$ and nitrification of urea and ammonium-N were rapid at this soil temperature. CAN and ASN (containing nitrate-N) gave higher pasture responses than AS (containing ammonium-N) and urea. Nitrate-N gave the best response when applied at soil temperature of $3-5^{\circ} \mathrm{C}$. Craighead et al. [63] further suggested that winter-active grasses (i.e. short-rotation ryegrass) could give a larger response to nitrate- $\mathrm{N}$ during early spring.

Table 5. Pasture Responses (kg DM ha ${ }^{-1}$ ) to $\mathrm{N}$ at Three Different Soil Temperatures

\begin{tabular}{|c|c|c|c|c|c|c|}
\hline \multirow{3}{*}{$\begin{array}{c}\text { N Fertiliser } \\
\text { Control }\end{array}$} & \multicolumn{6}{|c|}{ Soil Temperature } \\
\hline & \multicolumn{2}{|c|}{$0-2^{\circ} \mathrm{C}$} & \multicolumn{2}{|c|}{$3-5^{\circ} \mathrm{C}$} & \multicolumn{2}{|c|}{$7-9^{\circ} \mathrm{C}$} \\
\hline & 2380 & $(100)$ & 2170 & $(100)$ & 2510 & $(100)$ \\
\hline Urea & 2750 & (116) & 2830 & (130) & 2940 & (117) \\
\hline $\begin{array}{c}\text { Calcium } \\
\text { ammonium } \\
\text { nitrate }\end{array}$ & 3000 & (126) & 3280 & $(151)$ & 2970 & (118) \\
\hline $\begin{array}{l}\text { Ammonium } \\
\text { sulphate }\end{array}$ & 2740 & (115) & 2900 & (134) & 3110 & (124) \\
\hline $\begin{array}{l}\text { Ammonium } \\
\text { sulphate } \\
\text { nitrate }\end{array}$ & 2850 & (120) & 2820 & (130) & 3140 & (125) \\
\hline LSD $5 \%$ & 540 & & 350 & & 450 & \\
\hline
\end{tabular}

Slope and aspect have marked effects on soil moisture, soil temperature, light intensity [59] and N leaching, consequently affecting $\mathrm{N}$ responses. A study on dry hill country of Hawke's Bay in NZ showed that DM responses to $\mathrm{N}$ were greater in winter from steep $\left(25-30^{\circ}\right)$ north-facing aspects than easy $\left(15-20^{\circ}\right)$ south-facing slopes [60]. In other seasons, N DM responses were similar. Luscombe [64] also found aspect affected $\mathrm{N}$ use efficiency. In NZ during late winter, soil temperatures and light intensities in sheltered northerly aspects are more suitable for growth than those in shady, exposed aspects [59], therefore $\mathrm{N}$ response is greater in winter. However, if very steep north and westerly aspects are associated with shallow soils, then moisture stress, which often appears, even in periods of relatively frequent rainfall, limits $\mathrm{N}$ response [59]. As a result, $\mathrm{N}$ responses can vary even within a paddock on hill country.

\section{EFFECT OF NITROGEN USE ON SOIL NUTRIENTS AND PROPERTIES}

Dong et al. [41] applied $\mathrm{N}$ fertiliser at rates of 0,115 , 230 , and $345 \mathrm{~kg} \mathrm{~N}^{-1}$ to 3 mixtures of 4 perennial grasses, smooth brome grass (BI)+Elymus nutans $(\mathrm{EN}), \mathrm{BI}+$ E. sibricus $(\mathrm{ES})+$ Agropyron cristatum $(\mathrm{AC})$, and $\mathrm{BI}+\mathrm{ES}+\mathrm{EN}+\mathrm{AC}$ in the alpine region of Qinghai-Tibetan Plateau, China. Soil $\mathrm{pH}$ at harvesting time was not affected by $\mathrm{N}$ application rate. Soil dry bulk density and soil organic carbon at 0-30 cm were affected, but total soil $\mathrm{N}$ at $0-30 \mathrm{~cm}$ increased with $\mathrm{N}$ application rate and continued to increase after repeated application. After 3 years' consecutive $\mathrm{N}$ treatment, total soil $\mathrm{N}$ reached $13 \mathrm{~g} \mathrm{~kg}^{-1}$ at the $\mathrm{N}$ application rate of $345 \mathrm{~kg} \mathrm{ha}^{-1}$. Soluble soil $\mathrm{N}$ at $0-30 \mathrm{~cm}$ increased with application rate but decreased with application year. At $345 \mathrm{~kg} \mathrm{~N} \mathrm{ha}^{-1}$ application rate, soluble soil $\mathrm{N}$ was $>100 \mathrm{mg} \mathrm{kg}^{-1}$ in 1998 , but decreased to around $80 \mathrm{mg} \mathrm{kg}^{-1}$ in 2000 .

The loss of $\mathrm{Ca}$ in $\mathrm{NZ}$ pasture increased with increasing $\mathrm{N}$ application rate. The loss of $\mathrm{Ca}$ cation was highly correlated with the loss of nitrate $\mathrm{N}$, suggesting that $\mathrm{Ca}$ leaching is accompanied by nitrate anion [65].

The findings on the loss of $\mathrm{P}$ by $\mathrm{N}$ application are inconsistent. Williams and Young [66] reported that $\mathrm{N}$ application to a reseeded blanket bog caused $10 \%$ more $\mathrm{P}$ loss than the control. Roberts et al. [67] found that $\mathrm{N}$ application increased $\mathrm{P}$ concentrations in drainage from 0.05 to c. $0.3 \mathrm{mg}$ $\mathrm{L}^{-1}$ at an upland site in Wales. In contrast, Hawkins and Scholefield [68] did not find more P loss in drainage from grazed permanent grassland in Devon, England, after $\mathrm{N}$ application at rates of $200,400 \mathrm{~kg} \mathrm{~N}^{-1}$ per year. But McDowell and Monaghan [69] did find that the soil Olsen P and reductant-soluble (occluded) $\mathrm{P}$ concentrations significantly decreased after $\mathrm{N}$ application at rates of 200 and 400 $\mathrm{kg} \mathrm{N} \mathrm{ha}{ }^{-1}$ per year, suggesting $\mathrm{P}$ leaching increased with $\mathrm{N}$ application.

Soil properties were also affected by the $\mathrm{N}$ application. The application of $\mathrm{N}$ in soil had effects on the total soil microbial biomass, microbe community, soil animals, $\mathrm{C}$ and $\mathrm{N}$ mineralization, and soil enzyme activities related to the $\mathrm{C}, \mathrm{N}$ and $P$ cycles [70].

\section{CONCLUSIONS}

Nitrogen is a limiting factor for pasture production. Generally, the application of fertiliser $\mathrm{N}$ significantly increases the pasture yield. However, the efficiency of $\mathrm{N}$ application varies with plants, soils, seasons, climatic conditions and application techniques. To maximise the $\mathrm{N}$ use efficiency, these factors have to be taken into consideration. A pasture 
carryover effect can exist. However, this conclusion is arguable since few studies examined the recovery of residual fertiliser $\mathrm{N}$ from the re-growth pasture. A further study with $\mathrm{N}^{15}$-depleted fertiliser is required. $\mathrm{N}$ application influences not only pasture, but also soil properties and other soil nutrients. Furthermore, other effects including animal health, economic benefits, as well as environmental impacts, can result from the application of fertiliser N. Nitrogen applications should be systematically evaluated.

\section{REFERENCES}

[1] Ledgard SF, Sprosen MS, Penno JW, Rajendram GS. Nitrogen fixation by white clover in pastures grazed by dairy cows: Temporal variation and effects of nitrogen fertilization. Plant Soil 2001; 229: 177-87.

[2] Lambert MG, Clark DA, Litherland AJ. Advances in pasture management for animal productivity and health. NZ Vet J 2004; 52: 311-9.

[3] Hudson AW, Woodcock JW. Nitrogen dressing on dairy pastures. Experiments on production, seasons 1928-29 and 1929-30. J Agric 1931; 42: 99-115.

[4] O'Connor OCKF. Nitrogen and grassland production of the midaltitude zone of Canterbury, New Zealand. I. The effects of different levels of nitrogen fertiliser on herbage and nitrogen yields of cultivated pastures. NZ J Agric Res 1961; 4: 686-97.

[5] O'Connor OCKF. Nitrogen and grassland production of the midaltitude zone of Canterbury, New Zealand. II. The effects of different levels of calcium-ammonium nitrate on yields of cultivated pastures under different mowing frequencies. NZ J Agric Res 1961; 4: 698-708.

[6] O'Connor OCKF. Nitrogen and grassland production of the midaltitude zone of Canterbury, New Zealand. III. The effects of nitrogenous and other fertiliser materials on uncultivated pastures. NZ J Agric Res 1961; 4: 709-21.

[7] Molloy LF, Ball R, Collie TW, Ross DJ. Influence of fertiliser nitrogen on higher fatty acids and on $\mathrm{Mg}, \mathrm{Ca}, \mathrm{K}$, and $\mathrm{P}$ in grazed grass-clover herbage. NZ J Agric Res 1978; 21: 57-64.

[8] Ross DJ, Molloy LF, Collie TW, Ball R. Influence of fertiliser nitrogen on nitrogen fractions and nonstructural carbohydrates in grazed grass-clover herbage. NZ J Agric Res 1978; 21: 231-9.

[9] Lanmerink J. Effects of mid-spring applications of nitrogen on an irrigated pasture. NZ J Agric Res 1962; 5: 101-10.

[10] Hill MJ. The effects of time of application of nitrogen on seed yield of 'Grasslands Ruanui' ryegrass (Lolium perenne L.). Proc Agron Soc NZ 1972; 2: 5-10.

[11] Morton JD, McBride SD. Nitrogen use on Canterbury dryland pastures. Proc NZ Grassland Assn 1994; 56: 23-26.

[12] Mora MdelaL, Alfaro M, Williams P, Stehr W, Demanet R. Effect of fertilizer input on soil acidification in relation to growth and chemical composition of a pasture, and animal production. Rev Cienc Suelo Nutr Veg 2004; 4: 29-40.

[13] Ledgard SF, Sprosen MS, Brier GJ, Nemaia EKK, Clark DA. Nitrogen inputs and losses from New Zealand dairy farmlets, as affected by nitrogen fertilizer application: Year one. Plant Soil 1996; 181: 65-9.

[14] Ledgard SF, Sprosen MS, Steele KW. Nitrogen fixation by nine white clover cultivars in grazed pasture, as affected by nitrogen fertilization. Plant Soil 1996; 178: 193-203.

[15] Luo J, Ledgard SF, Lindsey SB. Nitrous oxide emissions from application of urea on New Zealand pasture. NZ J Agric Res 2007; 50: $1-12$

[16] Fageria NK, Baligar VC. Enhancing nitrogen use efficiency in crop plants. Adv Agron 2005; 88: 97-185.

[17] Ball PR, Field TRO. Responses to nitrogen as affected by pasture characteristics, season and grazing management. In: Lynch PB ed. Nitrogen Fertilisers in New Zealand Agriculture. Auckland, Ray Richards Publisher, 1982; pp. 45-64.

[18] Bahmani I, Thom ER, Matthew C, Hooper RJ, Lemaire G. Tiller dynamics of perennial ryegrass cultivars derived from different New Zealand ecotypes: Effects of cultivar, season, nitrogen fertiliser, and irrigation. Aust J Agric Res 2003; 54: 803-17.

[19] Lingorski V, Totev T, Mukhovski TS, et al. Effect of mineral fertilizer application on the yield and botanical composition of meadow grasses and grass mixtures in the Troyan region. Rasteniev" Nauk 1995; 32: 100-103.

[20] Ledgard SF, Sprosen MS, Steele KW, West CP. Productivity of white clover cultivars under intensive grazing, as affected by high nitrogen fertiliser application. NZ J Agric Res 1995; 38: 473-82.

[21] Harris SL, Clark DA. Effect of high rates of nitrogen fertiliser on white clover growth, morphology, and nitrogen fixation activity in grazed dairy pasture in northern New Zealand. NZ J Agric Res 1996; 39: 149-58.

[22] Steele KW. Quantitative measurements of nitrogen turnover in pasture systems with particular reference to the role of ${ }^{15} \mathrm{~N}$. Nuclear techniques in improving pasture management. International Atomic Energy Agency, Vienna 1983.

[23] Zemenchik RA, Albrecht KA. Nitrogen use efficiency and apparent nitrogen recovery of kentucky bluegrass, smooth bromegrass, and orchardgrass. Agron J 2002; 94: 421-8.

[24] Whitehead DC. The role of nitrogen in grassland productivity. A review of information from temperate regions, Farnham Royal Bucks UK: Commonwealth Agricultural Bureaux. 1970.

[25] O'Connor MB. Nitrogen fertilisers for the production of out-ofseason grass. In: Lynch PB ed. Nitrogen fertilisers in New Zealand Agriculture. Auckland, Ray Richards Publisher, 1982; pp. 65-76.

[26] Wedderburn ME, Tucker MA, Pengelly W J, Ledgard SF. Responses of a New Zealand North Island hill perennial ryegrass collection to nitrogen, moisture stress and grass grub (Costelytra zealandica) infestation. NZ J Agric Res 1990; 33: 405-11.

[27] Bahmani I, Thom ER, Matthew C, Lemaire G. Productivity of grazed perennial ryegrass dairy pastures from different ecotypes under nitrogen and irrigation treatments. NZ J Agric Res 2001; 44: 123-33.

[28] Feyter C, O'Connor MB, Addison B. Effects of rates and times of nitrogen application on the production and composition of dairy pastures in Waikato district, New Zealand. NZ J Exp Agri 1985; 13: 247-52.

[29] Smith LC, Morton JD, Catto WD, Trainor KD. Nitrogen responses on pastures in the southern South Island of New Zealand. Proc NZ Grassland Assn 2000; 62: 19-23.

[30] Martiniello P, Berardo N. Residual fertilizer effects on dry-matter yield and nutritive value of Mediterranean pastures. Grass Forage Sci 2007; 62: 87-99.

[31] Strong WM, Dalal RC, Weston EJ, Cooper JE, Lehane KJ, King AJ. Nitrogen fertiliser residues for wheat cropping in subtropical Australia. Aus J Agric Res 1996; 47: 695-703.

[32] Castle ML, Rowarth JS, Cornforth IS, Sedcole JR. Agronomical and physiological responses of white clover (Trifolium repens) and perennial ryegrass (Lolium perenne) to nitrogen fertiliser applied in autumn and winter. NZ J Agric Res 2002; 45: 283-93.

[33] Kim MC, Hyun HN, Lee SC. Botanical composition, herbage production and plant mineral contents as affected by application of chemical fertilizer and fermented sawdust pig manure on Cheju brown volcanic ash pasture soil. J Korean Soc Grassland Sci 2000; 20: 131-38.

[34] Galka A, Zarzycki J, Kopeca M. Effect of different fertilisation regimes on species composition and habitat in a long-term grassland experiment. Grassland Sci Eur 2005; 10: 132-5.

[35] Eltilib AM, Ledgard SF. Production and nitrogen fixation by 'Grasslands Kopu' and 'Grasslands Huia' white clovers under different nitrogen regimes. NZ J Agric Res 1988; 31: 325-30.

[36] Hardarson G, Atkins C. Optimising biological $\mathrm{N}_{2}$ fixation by legumes in farming systems. Plant Soil 2003; 252: 41-54.

[37] Cookson P, Goh KM, Swift RS, Steele KW. Effects of frequency of application of ${ }^{15} \mathrm{~N}$ tracer and rate of fertilizer nitrogen applied on estimation of nitrogen fixation by an established mixed grass/clover pasture using the ${ }^{15} \mathrm{~N}$ enrichment technique. NZ J Agric Res 1990; 33: 271-6.

[38] Marais JP. Factors affecting the nutritive value of kikuyu grass (Pennisetum clandestinum) - a review. Trop Grassland 2001; 35: 65-84.

[39] Keating T, O'Kiely P. Comparison of old permanent grassland, Lolium perenne and Lolium multiflorum swards grown for silage 3. Effects of varying fertiliser nitrogen application rate. Ir J Agric Food Res 2000; 39: 35-53.

[40] Jacobs JL, McKenzie FR, Kearney GA. Nitrogen fertilizer effects on nutritive characteristics of perennial ryegrass during late autumn, and mid- and late winter in western Victoria. Aust J Exp Agric 2002; 42: 541-8 
[41] Dong SK, Jiang Y, Wei MJ, Long RJ, Hu ZZ, Muyi K. Effects of nitrogen application rate on soil and plant characteristics in pastures of perennial grass mixtures in the alpine region of the Qinghai-Tibetan Plateau, China. Aust J Soil Res 2004; 42: 727-35.

[42] Pederson GA, Brink GE, Fairbrother TE. Nutrient uptake in plant parts of sixteen forages fertilized with poultry litter: nitrogen, phosphorus, potassium, copper, and zinc. Agron J 2002; 94: 895904.

[43] Gerdes L, de Mattos HB, Werner JC, et al. Chemical composition and digestibility of forage mass in irrigated aruanagrass pastures or oversown with a mixture of winter forage species. Rev Bras Zool 2005; 34: 1098-108

[44] Griffith SM, Alerman SC, Streeter DJ. Italian ryegrass and nitrogen source fertilization in western Oregon in two contrasting climatic years. I. Growth and seed yield. J Plant Nutr 1997; 20: 419-28.

[45] Griffith SM, Streeter DJ. Nitrate and ammonium nutrition in ryegrass: Changes in growth and chemical composition under hydroponic conditions. J Plant Nutr 1994; 17: 71-81.

[46] McKenzie FR, Jacobs JL, Ward GN. Irrigated dairy pasture yield and water use efficiency responses to summer applied nitrogen. Proc NZ Grassland Assn 2006; 68: 155-160.

[47] Whitehead DC. Grassland nitrogen. Wallingford, UK: CAB International. 1995.

[48] Bomke AA, Bertrand A. Response of an orchard grass-perennial ryegrass sward to rate and method of urea and ammonium nitrate application. Can J Soil Sc 1983; 63: 719-725.

[49] Simons RG, Gross ATH. Growth of four grass species as affected by rate of nitrogen application and year of establishment on two soil types. Can J Plant Sci 1985; 65: 581-8.

[50] Penno JW. A comparison of the effect of split and single applications of nitrogen fertiliser on dairy production. Proc NZ Soc Anim Prod 1993; 53: 33-5.

[51] Overman AR, Downey D, Wilkinson SR. Effect of $\mathrm{N}$ rate and split application on Bahiagrass production. Commun Soil Sci Plant Anal 1989; 20: 501-12.

[52] Malhi SS, Gill KS, Heier K, Lickacz J. Effects of single versus split annual applications of nitrogen on forage dry matter and protein yield of smooth bromegrass. Commun Soil Sci Plant Anal 2002; 33: 3797-808.

[53] Korte CJ. Nitrogen fertilizer responses on Gisborne-East Coast pastures. Proc Ann Confer Agron Soc NZ 1988; 18: 85-8.

[54] Banszki T. Results of delayed N fertilisation after cutting on intensively planted swards. Novenytermeles 1998; 47: 689-95.

[55] Rogers NI, Putt HB. Economic nitrogen response on wet Northland soils. Proc NZ Grassland Assn 1997; 59: 129-30.
[56] Wheeler DM, O'Connor MB. Why do pastures respond to lime? Proc NZ Grassland Assn 1998; 60: 57-61.

[57] Zhou JY, Valentine I, Hodgson J. Response of southern North Island hill pasture to nitrogen, molybdenum and lime. Proc NZ Grassland Assn 1993; 55: 63-6.

[58] Morton JD, Roberts AHC. Pasture production response to fertiliser on renovated West Coast Pakihi soils. Proc NZ Grassland Assn 2006; 68: 331-8.

[59] Every JP. An appraisal of nitrogen use on North Island hill country. In: Eighth research symposium (Nitrogen fertiliser---the changing New Zealand scene), edited by New Zealand Fertiliser Manufacturers' Research Association (Inc). 1983.

[60] Gillingham AG, Gray MH, Smith DR. Pasture responses to phosphorus and nitrogen fertilisers on dry hill country. Proc NZ Grassland Assn 1998; 60: 135-40.

[61] Williams PH, Paterson DJ. Response of pastures to nitrogen fertiliser applied in autumn and spring on the West Coast of South Island, New Zealand. NZ J Exp Agric 1983; 11: 247-50.

[62] Watson CJ, Adam SN. Effect of simulated wet spring conditions on the relative efficiency of three forms of $\mathrm{N}$ fertiliser on grassland. $\mathrm{J}$ Agric Sci 1986; 107: 219-22.

[63] Craighead MD, Hayward JA, Howie AM. Evaluation of nitrate fertilisers as nitrogen sources for spring pasture. Proc NZ Grassland Assn 1997; 59: 131-5.

[64] Luscombe PC. Seasonal nitrogen deficiency in hill country pastures. NZ J Exp Agric 1980; 8: 117-22.

[65] Edmeades DC, Perrott KW. The calcium requirements of pastures in New Zealand: A review. NZ J Agric Res 2004; 47: 11-21.

[66] Williams BL, Young M. Nutrient fluxes in runoff on reseeded blanket bog, limed and fertilized with urea, phosphorus and potassium. Soil Use Manag 1994; 10: 173-80.

[67] Roberts AM, Hudson JA, Roberts G. A comparison of nutrient losses following grassland improvement using two different techniques in an upland area of mid-Wales. Soil Use Manag 1989; 5: 174-79.

[68] Hawkins JMB, Scholefield D. Molybdatereactive phosphorus losses in surface and drainage waters from permanent grassland. J Environ Qual 1996; 25: 727-32.

[69] McDowell RW, Monaghan RM. The potential for phosphorus loss in relation to nitrogen fertiliser application and cultivation. NZ J Agric Res 2002; 45: 245-53.

[70] Pankhurst CE, Hawke BG, McDonal HJ, Kirkby CA, Michelsen P, O'Brien KA, Gupta VVSR, Doube BM. Evaluation of soil biological properties as potential bioindicators of soil health. Aus J Exp Agric 1995; 35: 1015-28.

(C) Sun et al.; Licensee Bentham Open.

This is an open access article distributed under the terms of the Creative Commons Attribution License (http://creativecommons.org/licenses/by/2.5/), which permits unrestrictive use, distribution, and reproduction in any medium, provided the original work is properly cited. 